Review

\title{
Exploratory Study on Modelling Agricultural Carbon Emissions in Ireland
}

\author{
Sinéad M. Madden ${ }^{1, *(\mathbb{D})}$, Alan Ryan ${ }^{1}(\mathbb{D})$ and Patrick Walsh ${ }^{2}(\mathbb{D}$ \\ 1 Faculty of Science and Engineering, University of Limerick, V94 T9PX Limerick, Ireland; Alan.Ryan@ul.ie \\ 2 Enterprise Research Unit, University of Limerick, V94 T9PX Limerick, Ireland; Patrick.Walsh@ul.ie \\ * Correspondence: Sinead.Madden@ul.ie
}

Citation: Madden, S.; Ryan, A.; Walsh, P. Exploratory Study on Modelling Agricultural Carbon Emissions in Ireland. Agriculture 2022, 12, 34. https://doi.org/10.3390/ agriculture12010034

Academic Editor: Weixin Ding

Received: 8 November 2021 Accepted: 24 December 2021 Published: 28 December 2021

Publisher's Note: MDPI stays neutral with regard to jurisdictional claims in published maps and institutional affiliations.

Copyright: (c) 2021 by the authors. Licensee MDPI, Basel, Switzerland. This article is an open access article distributed under the terms and conditions of the Creative Commons Attribution (CC BY) license (https:/ / creativecommons.org/licenses/by/ $4.0 /)$.

\begin{abstract}
In 2020 Ireland missed its EU climate emissions target and without additional measures will not be on the right trajectory towards decarbonisation in the longer 2030 and 2050 challenges. Agriculture remains the single most significant contributor to overall emissions in Ireland. In the absence of effective mitigating strategies, agricultural emissions have continued to rise. The purpose of the review is to explore current research conducted in Ireland regarding environmental modelling within agriculture to identify research gap areas for further research. 10 models were selected and reviewed regarding modelling carbon emissions from agriculture in Ireland, the GAINS (Air pollution Interactions and Synergies) model used for air pollutants, the JRC-EU-TIMES, (Joint Research CouncilEuropean Union-The Integrated MARKAL-EFOM System) and the Irish TIMES model used for energy, the integrated modelling project Ireland (GAINS \& TIMES), the environmental, economic model ENV-Linkages and ENV-Growth along with the IE3 and AGRI-I models. The review found that data on greenhouse gas emissions for 2019 reveals that emissions can be efficiently lowered if the right initiatives are taken. More precise emission factors and adaptable inventories are urgently needed to improve national $\mathrm{CO}_{2}$ reporting and minimise the agricultural sector's emissions profile in Ireland. The Climate Action Delivery Act is a centrally driven monitoring and reporting system for climate action delivery that will help in determining optimal decarbonisation from agriculture in Ireland. Multi-modelling approaches will give a better understanding of the technology pathways that will be required to meet decarbonisation ambitions.
\end{abstract}

Keywords: environmental modelling; mathematical modelling; computational modelling; carbon emissions; agriculture systems; Ireland

\section{Introduction}

The transition of Ireland's environment, society, and economy to a low-carbon, climateresilient state while reaching national and international targets is a top priority for policymakers. Ireland's government has passed a new climate law [1] that commits the country to become carbon-neutral by 2050. This will be accomplished by the Irish government through a 'National Climate 2050 Plan' [2]. The goal is for the state to make the transition to a climate-resilient economy by the year 2050. In 2020 Ireland missed its European Union (EU) climate emissions target and without additional measures will not be on the right trajectory towards decarbonisation in the longer 2030 and 2050 challenges. The EPA's published provisional carbon emissions data for 2018 highlighted that Ireland was not on track towards meeting its emission reduction targets despite a small overall emissions reduction-driven by reduced coal use in the Moneypoint power plant. When compared to the With Existing Measures scenario, Additional Measures (including those in the 2019 Climate Action Plan [2]) are expected to conserve $58 \mathrm{Mt} \mathrm{CO}_{2}$ eq over the period 2021-2030. This equates to a $1.8 \%$ reduction in emissions every year over the course of the term. Overall, the reduction in emissions in 2019 is a step in the right direction, with evidence of a significant move away from coal and peat in power generation, which the operators have 
pledged to continue. The influence of the COVID-19 pandemic throughout all sectors of the economy is expected to drive further reductions in emissions in 2020.

The Environmental Protection Agency's (EPA) published projections 2020-2040 [3] shows Ireland exceeded its 2013-2020 European Union Effort Sharing Decision objective by $12.2 \mathrm{Mt} \mathrm{CO} 2$ eq, but believes it can reach its current EU 2021-2030 target if the steps in the 2019 Climate Action Plan [2] are fully implemented. According to the EPA [3] this would result in a 2\% annual reduction in carbon emissions from 2021 to 2030, The overall implementation rate was $78 \%$ as of the end of quarter 4 2020, with 391 measures implemented out of a total of 500 required [4].

The EPA report [5] that agriculture continues to be the single largest contributor to overall emissions, accounting for $37.4 \%$, and is on track to surpass current levels, accounting for $39.7 \%$ of carbon emissions by 2030 . Teagasc, Ireland's Agriculture and Food Development Authority, conducted an updated review that informed the forecasts. This industry accounted for around $35.4 \%$ of Ireland's total emissions in 2019, with that percentage predicted to rise to $40 \%$ by 2030 (in the With Additional Measures scenario) [5]. This is due to grow steadily with a plan to increase the national herd [6]. Ireland's absolute agricultural carbon emissions rank 8th across the European Union (EU), contributing approx. $4.4 \%$ of EU agricultural emissions [7].

According to the most recent projections, total agricultural emissions grew by $9.4 \%$ from 1990 to 2019 , owing to a $16.1 \%$ increase in methane emissions from enteric fermentation and a $22.1 \%$ increase in emissions from manure management. Following an increasing trend in emissions in the 1990s, the Agriculture sector's emissions began to progressively drop between 1998 and 2011. However, emissions have been trending higher since 2011, with an overall peak observed in 2018. Meanwhile, since 1990, overall fossil fuel combustion emissions from agriculture, forestry, and fisheries have fallen by $18.3 \%$. Dairy cow numbers have climbed by $38.3 \%$ in the last 10 years, resulting in a $66.9 \%$ increase in milk production. This reflects national goals to increase milk production under the Food Wise 2025 strategy [6], as well as the abolition of milk quotas in 2015. Ireland's Food Wise 2025 strategy is taken into account when predicting carbon emissions. The Climate Action Plan 2019's implementation rates have ranged from quarter to quarter.

Agriculture emissions, while decreasing by a not-insignificant amount in 2019, did so primarily as a result of a reduction in fertiliser use and liming, which had both increased significantly in the previous year. There is as yet no firm indication that the 2019 trend is likely to result in a sustained long term decreasing in agriculture emissions, particularly given that dairy cow numbers continued to rise in 2019. The EPA, on the other hand, stated that if the steps outlined in the government's 2019 Climate Action Plan are properly implemented, the country will be able to reach the EU reduction objectives for 2021-2030. Between 2021 and 2030, this would result in a nearly $2 \%$ reduction in emissions per year $[8,9]$.

Agriculture emissions are predicted to fall by 1.2\% per year between 2021 and 2030, assuming the $16.5 \mathrm{MtCO}_{2}$ eq $\mathrm{CO}_{2}$ savings identified in the 2019 Climate Action Plan [2] are realised. In 2019, agriculture emissions declined by $4.0 \%$, or $0.88 \mathrm{Mt} \mathrm{CO}_{2} \mathrm{eq}$, due to lower nitrogen fertiliser use (down $-10.1 \%$ in 2019 ) and a reduction of $25.4 \%$ in the amount of lime applied to soils. However, with a $2.8 \%$ increase in dairy cow numbers in 2019, this reduction in emissions from the sector may be difficult to maintain (the 9th consecutive year of growth). There is no strong indication that the 2019 trend will result in a sustained long-term reduction in agriculture emissions, especially considering that dairy cow numbers have continued to climb [3,5]. Agriculture will need to play a key role in helping meet carbon emissions.

Ag Climatise [10], a national climate and air road map for the agricultural sector comprise various cross-cutting actions, including more research and innovation and the establishment of a climate-smart agriculture centre of excellence in Ireland. Land management initiatives are included in the road map, such as re-wetting carbon-rich soils to transform them from carbon sources to sinks. It also includes steps to build a pilot 
plan to compensate farmers for the carbon advantages of their farms. Agricultural carbon emissions are offset by carbon removals and a large increase in the use of renewable energy on farms. There are 29 measures with defined and ambitious goals to minimise the environmental footprint and strengthen Ireland's agricultural credentials. The program's goals are to lead and promote Ireland's transition to a more sustainable farming system, as well as to reduce agricultural emissions, with a the goal of reducing carbon emissions to between 17.5 and 19.0 metric tons of carbon dioxide equivalent by 2030. Ref. [11] writes on the challenge of sustainability for Irish agriculture and [12] on the feasibility of the nexus between agriculture and carbon emission targets in Ireland.

De Wit of Wageningen University, a pioneer of agricultural system modelling, presented agricultural production system models in the 1960s, believing that agricultural systems might be modelled by combining physical and biological principles. In 1965, he developed a methodology for calculating how different environmental conditions may affect the rate of photosynthesis of leaf canopies [13]. In 1987 he wrote on agricultural policy for sustainable agriculture [14] and in 1989 on simulation and modelling in agricultural systems [15]. The first studies on the global consequences of projected climate change on agricultural systems were conducted between 1990 and 1994 by [16]. These were the first studies to use crop and economic models to model global effects and set the way for a slew of other national and international climate change impact and adaptation studies. A number of models analysing carbon emissions reduction in agriculture through soil carbon absorption, afforestation, and reduced livestock emissions, as well as links between economic models and crop, livestock, hydrological, and ecosystem models, were developed in the 2000s, due to an increased interest in carbon emissions mitigation and ecosystem services. Between 2005 and 2010, the development of Earth system models [17], which are components of General Circulation Models (GCMs), led to the creation of novel methods for integrating crop simulation models to numerical climate model land surface schemes [18]. Relevant past literature reviews on agricultural systems modelling [19,20].

"Simulation" modelling, in contrast to more usual (largely economic) modelling, attempts to reflect the practical, real-world variety of dynamic interactions among individuals, groups and organisations that underlies the complex aggregate behaviour of human societies. In principle, it can better reflect the complexity of how societies respond to major stresses and the need for transformational change. Simulation modelling is not a replacement for more conventional techno-economic methods-different approaches are complementary, with distinct strengths in Society-wide Scenarios for Effective Climate Change Mitigation in different contexts. However, simulation modelling is specifically recommended for the study of scenarios of society-wide transformational change [21].

\section{Materials and Methods}

A scoping review is presented to explore current research regarding carbon emissions modelling within agriculture in Ireland to identify research gaps for further study and to ascertain what mathematical models are being used by decision-makers in Ireland. The following five steps were followed which followed the standards of a scoping review [22-25]: (i) determining the research issue, (ii) locating relevant studies, (iii) selecting eligible studies, (iv) graphing the data, and (v) compiling and summarising the findings.

The main research question is "which mathematical modelling methods are used by decision-makers regarding carbon emissions within agriculture in Ireland? The search conducted included published literature along with government reports and the search was conducted in 2020 and 2021. To ensure the reliability of the documents in this study the inclusion criteria used an initial search conducted on official public reports from the Government of Ireland, the Environmental Protection Agency (EPA) and Teagasc. Teagasc, is a national authority in Ireland that provides integrated research, advising, and training services to the agriculture and food sector as well as rural communities. The Irish Environmental Protection Agency (EPA) is an independent public entity charged 
with coordinating environmental research and enforcing environmental legislation in Ireland. They handle the Official inventory of carbon emissions in Ireland.

We performed a literature search using a mixture of forwarding and backward snowballing methods [26] using the search term "modelling carbon emissions agriculture Ireland" on Google, resulting in a paper by [8] published by Teagasc. Key documents were chosen from the citations of this paper and further searched for on Google Scholar and databases of Irish universities to further trace studies using modelling approaches used within agriculture in Ireland. This was supplemented by papers included in the reference lists of the traced documents and documents that were already known to us based on previous modelling studies exposure. We included only Government of Ireland reports and original research on carbon emissions within agriculture in Ireland. We included studies that applied a modelling method to account for carbon emissions from Irish agriculture. Land Use Regression models were not included as they model air quality and have no explicit reference to carbon emissions within agriculture in Ireland. We only included English language documents written mainly in the last 10 years and we conducted the last search in December 2021.

\section{Results}

To answer the question see Figure 1, 10 models were selected that matched the search criteria. The data collected from national agencies and peer-reviewed literature will be discussed and examples will show how environmental modelling supports decision making in Ireland regarding carbon emissions in agriculture. The most recent papers were chosen to identify gaps for further research.

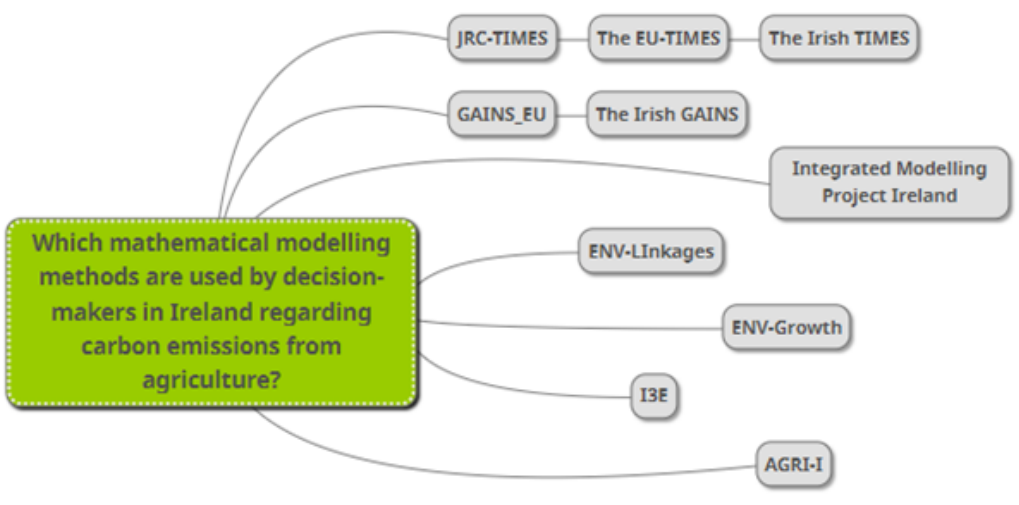

Figure 1. Environmental models used within agriculture for carbon emissions in Ireland.

\section{Discussion}

The purpose of this section is to synthesise the literature on environmental modelling methods which are a conventional approach to solving environmental-related problems within agriculture in Ireland. The discussion will investigate the use of mathematical and computational modelling, focusing on their utility in the abatement of Greenhouse Gas Emissions efforts in Ireland by 2050. The contribution will present an overview of environmentally-focused models used in Ireland and the European Union, such as the GAINS (Air pollution Interactions and Synergies) model, used for air pollutants. The JRCEU-TIMES (Joint Research Council-European Union-The Integrated MARKAL-EFOM System) and the Irish TIMES model used for energy, the integrated modelling project Ireland (GAINS and TIMES) and the environmental-economic model ENV-Linkages see Table 1. 
Table 1. Agricultural carbon emissions models used within agriculture in Ireland.

\begin{tabular}{ll}
\hline Abbreviation & Description \\
\hline JRC-EU-TIMES [27] & $\begin{array}{l}\text { Joint Research Council-EU-The Integrated MARKAL-EFOM } \\
\text { System, a linear optimisation bottom-up technology model }\end{array}$ \\
\hline The EU-TIMES [28] & $\begin{array}{l}\text { The Integrated MARKAL-EFOM System partial equilibrium } \\
\text { energy system model }\end{array}$ \\
\hline Irish TIMES [29] & $\begin{array}{l}\text { Irish The Integrated MARKAL-EFOM System, analyses en- } \\
\text { ergy usage, emissions, and natural resources }\end{array}$ \\
\hline EU GAINS [30] & $\begin{array}{l}\text { EU Greenhouse gas and Air Pollution Information and Simu- } \\
\text { lation, multi-sectoral integrated model }\end{array}$ \\
\hline Irish GAINS [31] & $\begin{array}{l}\text { Irish Greenhouse gas and Air Pollution Information and Sim- } \\
\text { ulation, multi-sectoral integrated model }\end{array}$ \\
\hline Integrated Modelling Project [32] & GAINS and TIMES \\
\hline ENV-Linkages [33,34] & Computable General Equilibrium (CGE) \\
\hline ENV-Growth [35] & Macroeconomic growth model \\
\hline I3E [36] & $\begin{array}{l}\text { Inter-temporal Computable General Equilibrium (CGE) } \\
\text { model }\end{array}$ \\
\hline AGRI-I [37] & Twin measurement modelling approach \\
\hline
\end{tabular}

\subsection{The JRC-EU-TIMES}

The JRC-EU-TIMES, (Joint Research Council-European Union-The Integrated MARKALEFOM System) model $[27,38]$ is a linear optimisation bottom-up technology model generated with the TIMES (The Integrated MARKAL-EFOM System) [28] model generator from the International Energy Agency. The JRC-EU-TIMES model takes into account both supply and demand and comprises the seven sectors of primary energy supply, power production, industry, residential, commercial, agriculture, and transport [39].

The EU-TIMES model is a partial equilibrium energy system model that is used to evaluate the utility of developing energy technologies. The JRC uses the POLES (Prospective Outlook on Long-Term Energy Systems) partial equilibrium energy system simulation model, the PRIMES (Price-Induced Market Equilibrium System Energy System), and the GEM-E3 General Equilibrium Model in the EU Road-map 2050 [40]. The PRIMES and GEM-E3 models are partial and general equilibrium models, respectively, that are utilised in the European Commission's official projections. The PRIMES model involves non-linear formulation for the power system optimisation, where non-linear cost-curves represent fuel supply, renewable potentials and limitations on the power plants' installation. The goal of GEM-E3 is to cover the linkages between the economy, energy system, and environment (E3). The TIMES (The Integrated MARKAL-EFOM System) model generator [28] was created as part of the IEA-energy ETSAP's scenario approach to conduct in-depth energy and environmental evaluations. The TIMES model generator combines two distinct but complementary approaches to energy modelling: technical engineering and economics. The European Environment Agency (EEA) offer a full list of models used within the European Union regarding environmental modelling efforts [41] and computer-based models in integrated environmental assessment [42].

\subsection{The Irish TIMES Model}

The Irish TIMES (The Integrated MARKAL-EFOM System) model is an energy system model that was developed by University College Cork (UCC) in collaboration with the Economic and Social Research Institute (ESRI), Energy Engineering Economic Environment Systems Modelling Analysis (E4SMA) and KanORS over the period March 2009-November 2011 [29]. The Irish TIMES (The Integrated Markal-EFOM System) is a model that analyses energy usage, emissions, and natural resources and was extracted from the Pan European TIMES (PET) model of Europe [43], and was then updated and expanded using local and 
more detailed data and assumptions [29]. The most common contemporary use of TIMES is in the study of programs aimed at reducing carbon emissions from energy and material use. It calculates the financial costs of a variety of climate mitigation initiatives $[29,44-46]$.

The Irish TIMES model generates a number of energy system configurations for Ireland, each of which meets predicted energy service demand requirements at the lowest cost possible while taking into account a variety of policy limitations up to 2050. It allows for the testing of energy policy options and scenarios, as well as the assessment of their implications for (a) the Irish economy (in specific areas such as energy prices, energy system investments, and marginal $\mathrm{CO}_{2}$ abatement costs), (b) Ireland's energy mix (fuels and technologies), and (c) the environment (mainly focusing on greenhouse gas emissions).

\subsection{The GAINS EU Model}

The International Institute for Applied Systems Analysis (IIASA) [47] funds the research programme Air Quality and Greenhouse Gases. The ultimate goal of AIR is to create innovative policies that maximise the advantages of climate and air quality activities while also achieving economic and social policy goals. AIR projects provide access to global databases on emissions and air pollution, as well as tools to investigate cost-effective emission control strategies in a variety of countries. In GAINS (Air pollution Interactions and Synergies) [30], three methods are provided for assessing policy interventions: simulations of the costs and health benefits of user-defined packages of emission control measures, cost-effectiveness analysis to determine the least-cost packages of policies that meet user-defined goals, and cost-benefit analysis to determine the least-cost packages of policies that meet user-defined goals.

\subsection{The Irish GAINS Model}

The GAINS Ireland model is run by EnvEcon under the EPA funded Integrated Modelling Project (IMP) Ireland which links national and EU modelling [31,48]. The GAINS Ireland is the national version of the GAINS Europe model. It is a multi-sectoral integrated model that was developed to provide effective decision support in relation to complex climate- and air-related questions. The major advantage of the GAINS Ireland system is that the model is a pivotal system at European and United Nations Economic Commission for Europe (UNECE) levels. Through these channels, the GAINS model informs and supports the ongoing development and management of climate and air policy across Europe. Pairing the nationally focused analytical capacity of GAINS Ireland with broader economic and environmental policy research has been a central goal. GAINS has also been adopted as the technical modelling backbone for international projects, such as the Climate and Clean Air Coalition. It draws on multiple national data sources such as the 1. Environmental Protection Agency (EPA), 2. Sustainable Energy Authority Ireland (SEAI), 3. Teagasc and 4. Industry.

The Irish GAINS Model uses a time horizon from 1990 to 2050 in five-year time steps and involves all EU Member States. Its impacts are on 1. Energy, 2. Transport, 3. Industry, 4. Agriculture, forestry, 5. Land use, 6. Atmospheric dispersion, 7. Health, 8. Ecosystems (acidification, eutrophication), 9. Macro-economy with multiple sectors, 10. Employment, and social welfare. Baseline emissions of $\mathrm{CO}_{2}$ emissions in the EU and policy scenarios for mitigation are estimated in a unified effort by the PRIMES [49], CAPRI [50], GAINS [30] and GLOBIOM [51] models. To maintain consistency in the creation of scenarios, the models are linked in formally defined ways.

In simple form the GAINS model can be structured under four segments, (i) activities, (ii) controls, (iii) emissions and (iv) effects. The 'Activities' segment defines the activities regarding energy use, agricultural data and a number of other relevant processes such as waste treatment or cement manufacture. The 'Control' segment relates to the abatement controls or emission savings options applied or available within the economy to control emissions. pollutants and $\mathrm{CO}_{2} \mathrm{~s}$. The 'Emissions' segment of the model combines the information on activities, controls and other interactions to determine the emissions to air 
of a broad range of air pollutants and carbon emissions. Finally, the 'Effects' segment uses mapping, dispersion, and other procedures to estimate the effects associated with a given scenario for a country or region [31].

\subsection{Integrated Modelling Project Ireland}

The Integrated Modelling Project Ireland (GAINS and TIMES) [32,52] represents a collaborative initiative between two national modelling teams in Ireland, EnvEcon and University College Cork (UCC) who have developed, manage, and run the GAINS Ireland and Irish TIMES models, respectively. While the models are distinct methodologically, they operate in a similar policy arena. The TIMES model focuses principally on energy systems and associated climate emissions, whereas the GAINS model is an integrated assessment model that focuses on both climate and air pollution. A key feature of GAINS, in this case, is its capacity to assess the interactions and synergies of policy across all sectors for the two thematic concerns. The GAINS Ireland and Irish TIMES are fundamentally different models. Linking the two allows the energy-focused optimisations of Irish TIMES to be analysed under the climate- and air-focused methodology of the GAINS model.

The models are both complex systems that address emissions and can run optimisations, but there are differences in scope, method, data structure and focus. Both models operate on an international scale and are developed for Irish use in aiding decision support. It is recognised within the academic literature that the models are not designed to operate in a formal integrated manner. There is value in examining how they may be used to complement and augment each other which allows the energy-focused optimisations of Irish TIMES to be analysed under the climate- and air-focused methodology of the GAINS model. The teams showed a soft link is possible as there is no automated solution to link the two models.

\subsection{ENV-Linkages Model}

The Organisation for Economic Co-operation and Development's (OECD) environmental economic modelling work is based on the in-house models ENV-Linkages $[33,34]$. The ENV-Linkages model is a neoclassical recursive dynamic General Equilibrium model (GE). A global economic model based mostly on a national economy database.

\subsection{The ENV-Growth Model}

ENV Growth [35], a macroeconomic growth model based on a conditional convergence framework, and [33], a dynamic general equilibrium model. The modelling effort aims to help governments discover the lowest-cost policies or policy combinations for reducing $\mathrm{CO}_{2}$ emissions, as well as estimating the cost and implications of environmental feedbacks, among other things. The model [35] is a two-sector model that forecasts global Gross Domestic Product (GDP) and per capita income levels for all major economies (currently more than 185 countries). The model is based on the conditional convergence of important economic drivers such as labour, human capital, physical capital, natural resources, and total factor productivity in different countries. The model is used to generate macroeconomic estimations for climate change Shared Socioeconomic Pathways (SSPs) and baseline predictions for ENV-Linkages.

\subsection{The I3E Computable General Equilibrium Model}

The Economic and Social Research Institute (ESRI) developed the I3E model [36,53-55] to forecast future greenhouse gas emissions and advise on climate policy planning in Ireland. It explains the link between energy inputs and environmental repercussions (with a focus on diverse emissions), as well as the relationship between production sectors, households, and the government. It completely replicates the economy's structure. The Computable General Equilibrium (CGE) model looks at how inputs and outputs flow between sectors of the economy, ending in final goods consumed by households. It can, for example, explore the economic repercussions of an energy tax in the transportation 
sector, which can be assessed both in terms of the transportation sector and other sectors via crossovers. It may replicate specific policies such as coal or carbon taxes, as well as monetary incentives for renewable energy sources. I3E is an intertemporal computable model of general equilibrium that examines Irish economy sectors. It incorporates multiple firms, multiple commodities, government, enterprise, and rest of the world accounts. It goes into great detail into each sector of the Irish economy. The model was created to explore the economic and environmental implications of climate policy in Ireland. It provides a full description of energy inputs and associated greenhouse gas emissions [56].

\subsection{AGRI-I Model}

Teagasc is a state-supported agricultural and food advisory authority in Ireland. The network allows Teagasc to teach, develop research, manage outcomes, and communicate directly with farmers and other stakeholders. Instead of using Tier 1 default values for $\mathrm{CO}_{2}$ emissions, AGRI-I has adopted a twin measurement and modelling strategy that will enable the transition to Tier 2 and Tier 3 country-specific approaches. Process models like DNDC [57], Daycent [58], and ECOSSE [59] are utilised to limit observational $\mathrm{N}_{2} \mathrm{O}$ and carbon sequestration data in AGRI-I,

\section{Limitations}

In the Irish TIMES model research the teams don't model non-energy related emissions linked with agriculture; instead, they use forecasts from other sources to exogenously set the energy system's aim. This enables assessments of what such climate optimisations imply for legally binding air pollutant targets for Ireland, and it further allows the estimation of air pollutant-related impact costs by using their marginal damage valuation methodology [31].

The outcomes of the GAINS model are in the form of carbon emissions and the associated effects (e.g., health impacts, acidification) and costs (e.g., abatement technology investments). The model can run at global, regional, national, and sectoral scales. Combining a number of complementary energy models to make decisions about low-carbon energy pathways at both the national and global levels is becoming more prevalent [60].

The following challenges were identified in GAINS and TIMES, Ireland possesses a modelling infrastructure that can usefully inform the negotiation and direction of national policy. Supplementing this modelling tailored with policy research will help to identify practical means of delivering better policy decisions for Ireland in the future [61].

There are two studies by the ESRI applying the I3E model to investigate the economic effects of increasing the Irish carbon tax. The analyses, which were released in March 2019 [62] and October 2019 [63], look into the effects of raising the Irish carbon tax in the years leading up to 2030. The first study analyses two carbon tax scenarios while the second study is concerned with the distributional impacts of an increased carbon tax depending on different revenue recycling schemes. The results of both studies suggest: carbon emissions would be significantly reduced by increasing the carbon tax, but not enough to bring Ireland close to reaching its EU emissions targets [64].

\section{New Developments}

This section briefly outlines some innovations in modelling methodology including expanding the scope to include mixed-methods modelling and Geographic Information System (GIS).

In the Irish Times model, further research is required to model energy-related and agriculture-related $\mathrm{CO}_{2}$ emissions to establish an overall least cost. Because there is no automated approach to link the two models, the teams demonstrated that a soft link is achievable. Ref. [65] uses the TIMES model to model climate and energy scenarios for Ireland up to 2050. Ref. [64] writes on technical support on developing a low carbon sector road-map for Ireland. The [29] report's analysis is based on a scenario analysis using the Irish TIMES energy systems model. The TIMES model used to look at baseline estimates as well as assess the consequences of future technologies and mobilises various policy 
options like renewable energy objectives and carbon mitigation methods. Agriculture outputs from FAPRI-Ireland were used in the construction of the agriculture module in TIMES [29]. Ireland's first outlook using FAPRI was in 1998, along with the first of many CAP reforms that occurred during this period. Over the years, FAPRI-Ireland has expanded its work to include farm sector analyses and environmental projections. Key Recommendations, "Open" data and modelling with clear documentation is strongly recommended. This can contribute strongly to a common understanding among researchers, citizens and decision-makers.

In the GAINS model multi-modelling approaches will aid in a better understanding of the technology pathways that will be required to meet decarbonisation ambitions. Using an energy systems optimisation model, a sectoral simulation model, and inspection of individual policy actions, the team devised a multi-model approach. The study looked into decarbonising the private car sector in Ireland's transportation system, aiming for an $80 \%$ decrease in national carbon emissions by 2050.

Within GAINS and TIMES, it is useful for the future [32], to have experience of reconciling the energy pathway recommendations from the Irish TIMES model with the GAINS Ireland modelling system. This technique will allow those pathways to be assessed in the familiar GAINS format by the European Commission or other international policy making bodies during the negotiation and review processes for global climate and air policy. This enables assessments of what such climate optimisations imply for legally binding air pollutant targets for Ireland, and it further allows the estimation of air pollutant-related impact costs by using their marginal damage valuation methodology [31]. Further research is needed to precisely assess the practicality of any increased biomass use in Ireland consistent with appropriate policies and technologies [32].

In the AGRI-I Geographic Information System (GIS), the land-use dataset would be used to extend the analysis to regional/national scales. The goal would be to evaluate the effectiveness of mitigation options across a variety of typical soil types and climate scenarios in the future. The data gathered would be invaluable for scenario testing as well as the creation of $\mathrm{CO}_{2}$ and land-use policies. AGRI-I could produce large amounts of data from both measurement and modelling efforts. The data sets must be standardised and quality-controlled to facilitate data exchange between partners and to ensure proper use and interpretation of the data. This would result in a dedicated database storing AGRI-I flux, soil, metadata (climate, management/activity data), and modelling output data. More precise emission factors and adaptable inventories are urgently needed to improve national $\mathrm{CO}_{2}$ reporting and minimise the agricultural sector's emissions profile [37].

\section{Conclusions}

The review found that data on greenhouse gas emissions for 2019 reveals that emissions can be efficiently lowered if the right initiatives are taken. When compared to the With Existing Measures scenario, Additional Measures (including those in the 2019 Climate Action Plan) [2] are expected to conserve $58 \mathrm{Mt} \mathrm{CO}_{2}$ eq over the period 2021-2030. More precise emission factors and adaptable inventories are urgently needed to improve national $\mathrm{CO}_{2}$ reporting and minimise the agricultural sector's emissions profile [37]. The Climate Action Delivery Act [4] is a centrally driven monitoring and reporting system for climate action delivery that may help in determining the optimal reduction in carbon emissions from agriculture in Ireland.

The results highlight the importance of integrated policy analysis which needs to take a broader perspective with national decision-making which considers a policy change from multiple angles such as air, climate, economy, and health. Principal sources of official modelling and research in Ireland would be linked to the EPA and Teagasc, as well as the corresponding parent Department of Agriculture, Food and the Marine (DAFM). Multimodelling approaches will aid in a better understanding of the technology pathways that will be required to meet decarbonisation ambitions. Further research should assess the directly corresponding health and environmental impacts from carbon emissions from 
agriculture that could otherwise occur due to associated increases in the levels of air pollutants across Ireland.

Author Contributions: Conceptualisation, S.M.M.; Methodology, S.M.M.; Formal Analysis, S.M.M.; Investigation, S.M.M.; Resources, S.M.M.; Data Curation, S.M.M.; Writing-Original Draft Preparation, S.M.M.; Writing—Review \& Editing, S.M.M.; Visualisation, S.M.M.; Supervision, A.R. and P.W.; Project Administration, S.M.M.; Funding Acquisition, S.M.M. All authors have read and agreed to the published version of the manuscript.

Funding: This research was partially funded by University of Limerick, Ireland.

Acknowledgments: The main author would like to thank Alan Ryan and Patrick Walsh for their support and guidance throughout these studies.

Institutional Review Board Statement: Not applicable.

Informed Consent Statement: Not applicable.

Conflicts of Interest: The authors declare no conflict of interest.

\section{References}

1. Government of Ireland. Government Publishes New Climate Law Which Commits Ireland to Net Zero Carbon Emissions by 2050. 2019. Available online: https://www.gov.ie/en/press-release/aecb3-government-publishes-new-climate-law-whichcommits-ireland-to-net-zero-carbon-emissions-by-2050 (accessed on 23 December 2021).

2. Government of Ireland. Climate Action Plan. 2019. Available online: https://assets.gov.ie/25419/c97cdecddf8c49ab976e773d4e1 1e515.pdf (accessed on 23 December 2021).

3. Environmental Protection Agency. Ireland's Final Greenhouse Gas Emissions 2019. 2021. Available online: https://www.epa.ie/ publications/monitoring--assessment/climate-change/air-emissions/EPA-GHG-Inventory-Report-Final.pdf (accessed on 23 December 2021).

4. Government of Ireland. Interim Climate Actions. 2021. Available online: https://assets.gov.ie/136661/92c35cd6-e77d-4b81-8132 -dac842b89339.pdf (accessed on 23 December 2021).

5. Environmental Protection Agency. Ireland's Greenhouse Gas Emissions Projeections 2020-2040. 2021. Available online: https://www.epa.ie/publications/corporate/governance/EPA_AnnualReport_English_2019web.pdf (accessed on 23 December 2021).

6. Philip Farrelly \& Co Limited. Food, Wise, Assessment Strategic Environmental Assessment 2025. 2015. Available online: https:/ / assets.gov.ie/109099/26babf65-e7a5-48e9-bb96-887c4ebbf1ab.pdf (accessed on 23 December 2021).

7. Government of Ireland. Fact Sheet on Irish Agriculture. 2018. Available online: http://edepositireland.ie/bitstream/handle/22 62/94910/IrishAgricultureFactsheetFullYear2018010519.pdf?sequence=1\&isAllowed=y (accessed on 23 December 2021).

8. Lanigan, G.; Donnellan, T.; Hanrahan, K.; Carsten, P.; Shalloo, L.; Krol, D.; Forrestal, P.J.; Farrelly, N.; O’Brien, D.; Ryan, M.; others. An Analysis of Abatement Potential of Greenhouse Gas Emissions in Irish Agriculture 2021-2030. Technical Report. 2018. Available online: https:/ / www.teagasc.ie/media/website/publications/2018/An-Analysis-of-Abatement-Potential-ofGreenhouse-Gas-Emissions-in-Irish-Agriculture-2021-2030.pdf (accessed on 23 December 2021).

9. Donnellan, T.; Hanrahan, K.; Lanigan, G. Future Scenarios for Irish Agriculture: Implications for Greenhouse Gas and Ammonia Emissions; Teagasc: Athenry, Ireland, 2018.

10. Government of Ireland. Ag Climatise National Climate Air Roadmap for the Agriculture Sector. 2020. Available online: https: / / www.gov.ie/en/press-release/a8823-publication-of-ag-climatise-national-climate-air-roadmap-for-the-agriculture-sector (accessed on 23 December 2021).

11. Castle, A.J. The Challenge of Sustainability for Irish Agriculture. 2019. Available online: https://t-stor.teagasc.ie/bitstream/ handle/11019/2540/Karl-Richards-The-Challenge-for-Sustainability-for-Irish-Agriculture-compressed.pdf?sequence=1\& isAllowed $=y$ (accessed on 23 December 2021).

12. Adenaeuer, L.; Hayden, A.; Breen, J. Feasibility of the Nexus of Agricultural and Greenhouse Gas Emission targets in the case of Ireland. Technical Report. 2019. Available online: https://ageconsearch.umn.edu/record/289672 (accessed on 23 December 2021).

13. De Wit, C.T. Photosynthesis of Leaf Canopies. Technical Report, Pudoc. 1965. Available online: https://edepot.wur.nl/187115 (accessed on 23 December 2021).

14. De Wit, C.; Huisman, H.; Rabbinge, R. Agriculture and its environment: Are there other ways? Agric. Syst. 1987, 23, 211-236. [CrossRef]

15. Rabbinge, R.; De Wit, C. Systems, models and simulation. In Simulation and Systems Management in Crop Protection; Pudoc: Wageningen, The Netherlands, 1989; pp. 3-15.

16. Rosenzweig, C.; Parry, M.L. Potential impact of climate change on world food supply. Nature 1994, 367, 133-138. [CrossRef]

17. Southern Ocean Carbon and Climate Observations and Modeling (SOCCOM). Earth System Model (ESM); Princeton University. 2021. Available online: https:// soccom.princeton.edu/content/what-earth-system-model-esm (accessed on 23 December 2021). 
18. Challinor, A. Towards the development of adaptation options using climate and crop yield forecasting at seasonal to multi-decadal timescales. Environ. Sci. Policy 2009, 12, 453-465. [CrossRef]

19. Jones, J.W.; Antle, J.M.; Basso, B.; Boote, K.J.; Conant, R.T.; Foster, I.; Godfray, H.C.J.; Herrero, M.; Howitt, R.E.; Janssen, S.; et al. Brief history of agricultural systems modeling. Agric. Syst. 2017, 155, 240-254. [CrossRef]

20. Peart, R.M.; Shoup, W.D. Agricultural Systems Modeling and Simulation; CRC Press: Boca Raton, FL, USA, 2018.

21. McMullin, B.; Price, P.R. Society-Wide Scenarios for Effective Climate Change Mitigation in Ireland (Technical Report). 2020. Available online: https:/ / www.epa.ie/publications/research/climate-change/Research_Report_352.pdf (accessed on 23 December 2021).

22. Levac, D.; Colquhoun, H.; O'Brien, K.K. Scoping studies: advancing the methodology. Implement. Sci. 2010, 5, 1-9. [CrossRef]

23. Colquhoun, H.L.; Levac, D.; O’Brien, K.K.; Straus, S.; Tricco, A.C.; Perrier, L.; Kastner, M.; Moher, D. Scoping reviews: Time for clarity in definition, methods, and reporting. J. Clin. Epidemiol. 2014, 67, 1291-1294. [CrossRef]

24. Pham, M.T.; Rajić, A.; Greig, J.D.; Sargeant, J.M.; Papadopoulos, A.; McEwen, S.A. A scoping review of scoping reviews: Advancing the approach and enhancing the consistency. Res. Synth. Methods 2014, 5, 371-385. [CrossRef] [PubMed]

25. Tricco, A.C.; Lillie, E.; Zarin, W.; O’Brien, K.; Colquhoun, H.; Kastner, M.; Levac, D.; Ng, C.; Sharpe, J.P.; Wilson, K.; et al. A scoping review on the conduct and reporting of scoping reviews. BMC Med. Res. Methodol. 2016, 16, 1-10. [CrossRef]

26. Wohlin, C. Guidelines for snowballing in systematic literature studies and a replication in software engineering. In Proceedings of the 18th International Conference on Evaluation and Assessment in Software Engineering-EASE'14, London, UK, 13-14 May 2014; ACM Press: New York, NY, USA, 2014; [CrossRef]

27. Nijs, W.; Ruiz, P. 01_JRC-EU-TIMES Full Model. European Commission, Joint Research Centre (JRC) [Dataset]. 2019. Available online: http:/ / data.europa.eu/89h/8141a398-41a8-42fa-81a4-5b825a51761b (accessed on 23 December 2021).

28. Loulou, R.; Remme, U.; Kanudia, A.; Lehtila, A.; Goldstein, G. Documentation for the Times Model Part ii. Energy Technol. Syst. Anal. Programme 2005, 8. Available online: https://www.iea-etsap.org/docs/Documentation_for_the_TIMES_Model-Part-II.pdf (accessed on 23 December 2021).

29. Ó Gallachóir, B.P.; Chiodi, A.; Gargiulo, M.; Deane, P.; Lavigne, D.; Rout, U.K. Irish Times Energy Systems Model. 2012. Available online: https://www.epa.ie/publications/research/climate-change/Irish-TIMES-Energy-Systems-Model.PDF (accessed on 23 December 2021).

30. International Institute for Applied Systems Analysis (IIASA). GAINS Online Greenhouse Gas-Air Pollution Interactions and Synergies. 2016. Available online: https://gains.iiasa.ac.at/models/index.html (accessed on 23 December 2021).

31. Envecon. Agriculture-Research \& Modelling Ireland, 2015. Available online: http://www.impireland.ie/downloads/tfiam-44 -agriculture-presentation-kelly-release.pdf (accessed on 23 December 2021).

32. Kelly, Andrew. Integrated Modelling Project Ireland, Climate Change Research Programme (CCRP) 2007-2013 Report Series No. 12, 2007. Available online: https://www.epa.ie/publications/research/air/CCRP_12web.pdf (accessed on 23 December 2021).

33. Burniaux, J.M.; Château, J. An Overview of the OECD Env-Linkages Model. 2008. Available online: https://www.oecd.org/ env /45334643.pdf (accessed on 23 December 2021).

34. Château, J.; Dellink, R.; Lanzi, E. An Overview of the OECD Env-Linkages Model: Version 3. 2014. Available online: https:/ / www.oecd-ilibrary.org/environment-and-sustainable-development/an-overview-of-the-oecd-env-linkages-model_ 5jz2qck2b2vd-en (accessed on 23 December 2021).

35. Château, J.; Dellink, R.; Lanzi, E.; Magné, B. The ENV-Growth Model: Global Reference Secnarios for Future Economic Growth. Technical Report, OECD Working Paper. 2013. Available online: https:/ /www.oecd.org/environment/indicators-modellingoutlooks / Flyer\%20ENV-Growth\%20model\%20-\%20version\%2025\%20Sept\%202013.pdf (accessed on 23 December 2021).

36. Denny, K.; Hannan, A.; O’Rourke, K.H. A Computable General Equilibrium Model of the Irish Economy: Technical Appendix. 1995. Available online: http:/ / hdl.handle.net/10197/1956 (accessed on 23 December 2021).

37. AGRI-I. Modelling and Data Collection. 2021. Available online: https://agri-i.ie/portfolio-items/modelling-data-collation/ (accessed on 23 December 2021).

38. Simoes, S.; Nijs, W.; Ruiz, P.; Sgobbi, A.; Radu, D.; Bolat, P.; Thiel, C.; Peteves, S. The Jrc-eu-Times Model. Assessing the Long-Term Role of the SET Plan Energy Technologies. 2013. Available online: https:/ / publications.jrc.ec.europa.eu/repository/ handle/JRC85804 (accessed on 23 December 2021).

39. Chiodi, A.; De Miglio, R.; Gargiulo, M.; Kanudia, A.; Nijs, W.; Politis, S.; Ruiz, P.; Zucker, A. JRC-EU-TIMES 2017 Upgrade. 2017. Available online: https:/ / publications.jrc.ec.europa.eu/repository/handle/JRC110037 (accessed on 23 December 2021).

40. Hübler, M.; Löschel, A. The EU decarbonisation roadmap 2050—what way to walk? Energy Policy 2013, 55, 190-207. [CrossRef]

41. European Environmental Agency. Modelling Environmental Change in Europe Towards a Model Inventory, Technical Report No 11/200. 2008. Available online: https://www.eea.europa.eu/publications/technical_report_2008_11 (accessed on 23 December 2021).

42. Peirce, M. Computer-Based Models in Integrated Environmental Assessment. European Environment Agency Publication, Technical Report. 1998. Available online: https:/ / www.eea.europa.eu/publications/TEC14 (accessed on 23 December 2021).

43. Gargiulo, M.; Gallachóir, B.Ó. Long-term energy models: Principles, characteristics, focus, and limitations. Wiley Interdiscip. Rev. Energy Environ. 2013, 2, 158-177. [CrossRef]

44. Chiodi, A.; Donnellan, T.; Breen, J.; Deane, P.; Hanrahan, K.; Gargiulo, M.; Ó Gallachóir, B.P. Integrating agriculture and energy to assess GHG emissions reduction: A methodological approach. Clim. Policy 2016, 16, 215-236. [CrossRef] 
45. Yue, X.; Deane, J.; O'Gallachoir, B.; Rogan, F. Identifying decarbonisation opportunities using marginal abatement cost curves and energy system scenario ensembles. Appl. Energy 2020, 276, 115456. [CrossRef]

46. Yue, X.; Patankar, N.; Decarolis, J.; Chiodi, A.; Rogan, F.; Deane, J.; O'Gallachoir, B. Least cost energy system pathways towards 100\% renewable energy in Ireland by 2050. Energy 2020, 207, 118264. [CrossRef] [PubMed]

47. Amann, M.; Bertok, I.; Borken-Kleefeld, J.; Cofala, J.; Heyes, C.; Höglund-Isaksson, L.; Klimont, Z.; Nguyen, B.; Posch, M.; Rafaj, P.; others. Cost-effective control of air quality and greenhouse gases in Europe: Modeling and policy applications. Environ. Model. Softw. 2011, 26, 1489-1501. [CrossRef]

48. King, F.; Fu, M.; Kelly, J.A. A practical approach for the assessment and illustration of uncertainty in emissions modelling: A case study using GAINS Ireland. Environ. Sci. Policy 2011, 14, 1018-1027. doi: 10.1016/j.envsci.2011.07.013. [CrossRef]

49. E3MLab. Primes Model Version 2018, Detailed Model Description. Technical Report. Available online: https://e3modelling. com/wp-content/uploads/2018/10/The-PRIMES-MODEL-2018.pdf (accessed on 23 December 2021).

50. Barreiro Hurle, J.; Bogonos, M.; Himics, M.; Hristov, J.; Perez Dominguez, I.; Sahoo, A.; Salputra, G.; Weiss, F.; Baldoni, E.; Elleby, C. Modelling Environmental and Climate Ambition in the Agricultural Sector with the CAPRI Model. Technical Report, Joint Research Centre (Seville Site). 2021. Available online: https://publications.jrc.ec.europa.eu/repository/handle/JRC121368 (accessed on 23 December 2021).

51. International Institute for Applied Systems Analysis (IIASA). GLOBIOM Documentation 2018. Available online: https: / /iiasa.ac.at/web/home/research/GLOBIOM/GLOBIOM.html (accessed on 23 December 2021).

52. Kelly, A.; Chiodi, A.; Fu, M.; Deane, P.; Gallachóir, B.P.Ó. Climate and Air Policy in Ireland: Synergies and Tensions-A GAINS Ireland and Irish TIMES Analysis. 2013. Available online: https://www.epa.ie/publications/research/climate-change/EPA_ Research-212_webEssentra.pdf (accessed on 23 December 2021).

53. De Bruin, K.; Yakut, A.M. Technical Documentation of I3E Model Version 2. Economic and Social Research Institute Survey and Statistical Report Series Number 77 September 2019. 2019. Available online: http:/ / aei.pitt.edu/101814/ (accessed on 23 December 2021).

54. De Bruin, K.; Yakut, A.M. Technical Documentation of the I3E Model, V4. 0. 2021. Available online: https://doi.org/10.26504 / sustat109 (accessed on 23 December 2021).

55. De Bruin, K.; Monaghan, E.; Yakut, A.M.; others. The Use of the I3E Model in Macroeconomic Analysis for the Irish Economy. Technical Report. 2020. Available online: http:/ / aei.pitt.edu/103545/1/WP679.pdf (accessed on 23 December 2021).

56. De Bruin, K.C.; Yakut, A.M. The Economic and Environmental Impacts of Increasing the Irish Carbon Tax. Technical Report, Research Series. 2018. Available online: https://www.esri.ie/publications/the-economic-and-environmental-impacts-ofincreasing-the-irish-carbon-tax (accessed on 23 December 2021).

57. Li, C. The DNDC Model. In Evaluation of Soil Organic Matter Models; Springer: New York, NY, USA, $1996 ;$ pp. $263-267$.

58. Del Grosso, S.; Parton, W.; Mosier, A.; Hartman, M.; Brenner, J.; Ojima, D.; Schimel, D.; others. Simulated interaction of carbon dynamics and nitrogen trace gas fluxes using the DAYCENT model. Model. Carbon Nitrogen Dyn. Soil Manag. 2001, $303,332$.

59. Smith, J, Gottschalk P, Bellarby J, Richards M, Nayak D, Coleman K, Hillier J, Flynn H, Wattenbach M, Aitkenhead M, and others. Model to estimate carbon in organic soils—Sequestration and emissions (ECOSSE). Carbon 2010, 44, 1-73.

60. Mulholland, E.; Rogan, F.; Gallachóir, B.Ó. From technology pathways to policy roadmaps to enabling measures-A multi-model approach. Energy 2017, 138, 1030-1041. [CrossRef]

61. Parson, E.A.; Fisher-Vanden.; Karen. Integrated assessment models of global climate change. Annu. Rev. Energy Environ. 1997, 22, 589-628. [CrossRef]

62. De Bruin, K.; Yakut, A.M. The Effects of an Incremental Increase in the Irish Carbon Tax towards 2030. Technical Report, ESRI Working Paper. 2019. Available online: https://www.esri.ie/publications/the-effects-of-an-incremental-increase-in-the-irishcarbon-tax-towards-2030 (accessed on 23 December 2021).

63. De Bruin, K.C.; Monaghan, E.; Yakut, A.M. The Economic and Distributional Impacts of an Increased Carbon Tax with Different Revenue Recycling Schemes; Number 95, Research Series, 2019. Available online: https://www.esri.ie/publications/theeconomic-and-distributional-impacts-of-an-increased-carbon-tax-with-different (accessed on 23 December 2021).

64. Deane, P.; Curtis, J.; Chiodi, A.; Gargiulo, M.; Rogan, F.; Dineen, D.; Glynn, J.; FitzGerald, J.; Gallachóir, B.Ó. Technical Support on Developing Low Carbon Sector Roadmaps for Ireland. Department of Environment, Community and Local Government. 2013. Available online: https:/ / www.esri.ie/system/files?file=media / file-uploads/2015-07 / BKMNEXT292.pdf (accessed on 23 December 2021).

65. Chiodi, A.; Gargiulo, M.; Rogan, F.; Deane, J.; Lavigne, D.; Rout, U.K.; Gallachóir, B.P.Ó. Modelling the impacts of challenging 2050 European climate mitigation targets on Ireland's energy system. Energy Policy 2013, 53, 169-189. [CrossRef] 